\title{
AVALIAÇÃO DE DESEMPENHO NA EXPERIÊNCIA DE GESTÃO COLABORATIVA DO INSS NO SEGURO DEFESO ${ }^{1}$
}

\author{
Luiz Henrique Alonso de Andrade²
}

De forma a contornar as restrições que enfrenta na concessão do Seguro Defeso, o INSS adotou uma política de gestão colaborativa, por meio de parcerias com as entidades representativas dos pescadores artesanais. Este artigo verifica a hipótese de que a política adotada pode ser capaz de promover ganhos de desempenho sob as dimensões de efetividade e equidade, na perspectiva do próprio pescador, na região do litoral sul da Bahia. É empregado o método de diferenças em diferenças, comparando indicadores entre os pescadores atendidos de forma convencional e aqueles objetos da intervenção, durante os períodos de defeso do camarão no Nordeste em 2015 e 2016. Os resultados são complementados com informações levantadas em entrevistas com gestores do INSS e representantes dos pescadores. Não apenas são verificados ganhos significativos de desempenho, mas também são apontadas restrições de natureza qualitativa.

Palavras-chave: avaliação de desempenho; seguro defeso; gestão colaborativa.

\section{PERFORMANCE EVALUATION ON INSS COLLABORATIVE MANAGEMENT EXPERIENCE ON SEGURO DEFESO}

The Brazilian National Social Security Agency (INSS), Brazil's main social allowance provider, recently adopted a new design for collaborative management policy initiatives on service delivery processes. This paper intends to assess its performance in the case of "Seguro Defeso", a benefit paid to artisanal fishermen during the closed fishing seasons, in the southern coast of Bahia. The evaluation is carried out in two dimensions of performance: effectiveness and equity, strictly from the perspective of the artisanal fisherman targeted by the Seguro Defeso program. The differencesin-differences method is used, comparing conventionally treated fishermen with those subject to the intervention in 2015 and in 2016. Results are complemented by interviews with agency managers and fishermen's representatives. The conclusion shows significant performance gains; however, qualitative restrictions are also reported.

Keywords: performance evaluation; collaborative management; cross-sectoral partnerships.

\section{EVALUACIÓN DE DESEMPEÑO EN LA EXPERIENCIA DE GESTIÓN COLABORATIVA DEL INSS EN EL SEGURO DEFESO}

Con el fin de superar las restricciones que enfrenta en la concesión del Seguro Defeso, el Instituto Nacional de la Seguridad Social (INSS) adoptó una política de gestión colaborativa, a través de alianzas con las entidades representativas de los pescadores artesanales. El presente artículo verifica la hipótesis de que la política adoptada puede ser capaz de promover mejora de desempeño bajo las dimensiones de Efectividad y Equidad, en la perspectiva del propio pescador, en la región del litoral sur de Bahía. Se emplea el método de diferencias-en-diferencias, comparando indicadores

1. DOI: http://dx.doi.org/10.38116/ppp56art8

2. Técnico do seguro social do Instituto Nacional do Seguro Social (INSS).E-mail: <henrique.ires@gmail.com>. 
del atendimiento a los pescadores en las temporadas de veda del camarón en el Nordeste en 2015 y 2016. Los resultados se complementan con informaciones levantadas en entrevistas con gestores del INSS y representantes de los pescadores. Se verifican mejoras significativas de desempeño, pero son apuntadas restricciones de naturaleza cualitativa.

Palabras clave: evaluación de desempeño; gestión colaborativa; colaboración multisectorial.

\title{
ÉVALUATION DU RENDEMENT SUR L'EXPÉRIENCE DE LA GESTION COLLABORATIVE DE L'INSS SUR SEGURO DEFESO
}

\begin{abstract}
L'Institut Nationale de Sécurité Sociale du Brésil (INSS), principal fournisseur d'allocations sociales au Brésil, a récemment adopté une nouvelle conception d'initiatives de politique de gestion collaborative sur les processus de prestation de services. Ce travail vise à évaluer les effets sur le rendement dans le cas du "Seguro Defeso», un avantage versé aux pêcheurs artisanaux pendant les périodes de fermeture de la pêche, sur la côte sud de Bahia. L'évaluation porte sur deux dimensions de la performance, de l'efficacité et de l'équité, strictement du point de vue du pêcheur artisanal visé par le programme Seguro Defeso. La méthode des différences dans les différences est utilisée pour comparer les pêcheurs traités de manière conventionnelle à ceux qui ont été soumis à l'intervention en 2015 et en 2016. Les résultats sont complétés par des entretiens avec des responsables d'agences et des représentants des pêcheurs. La conclusion montre des gains de performance significatifs; Cependant, des restrictions qualitatives sont également signalées.
\end{abstract}

Mots-clés: évaluation de la performance; gestion collaborative; partenariats intersectoriels.

JEL: H110; H830.

\section{INTRODUÇÃO}

O Instituto Nacional do Seguro Social (INSS) é a maior autarquia do governo federal e um grande representante do welfare State brasileiro. Além de operacionalizar os benefícios do Regime Geral de Previdência Social (RGPS), concede benefícios assistenciais, trabalhistas e indenizatórios. Nos últimos anos, o envelhecimento da força de trabalho e a ampliação de competências do instituto desequilibraram a relação demanda-oferta de seus serviços (Brasil, 2014a). Essa situaçáo foi agravada com progressivas restriçóes orçamentárias do governo federal, o que levou a administração a investir no redesenho de seus processos, culminando no desenvolvimento de estratégias de gestão pública colaborativa.

Para além da "delegação" da prestação de serviços a agentes externos, há hoje significativo repertório de modelos de governança para implementação de políticas públicas (O’Toole, 1997; Goldsmith e Eggers, 2004; Osborne et al., 2015; Bovaird, 2016), ampliado pelas possibilidades da tecnologia da informação - TI (Schuppan, 2009). Nesse sentido, o INSS desenvolveu o primeiro protótipo de ferramenta tecnológica para viabilizar modelos colaborativos de atendimento, o requerimento eletrônico (eReq), ${ }^{3}$ utilizado no Rio de Janeiro em 2014.

3. 0 eReq foi desenvolvimento e testado na cidade do Rio de Janeiro com empresas conveniadas entre outubro e novembro de 2014, a partir da publicação da Portaria no 1.184 da Presidência do INSS (Pres/INSS), de 30 de setembro de 2014 (INSS, 2014). 
Aprovado o conceito do eReq, ao final de 2016, o investimento trouxe a evolução para o gerenciador de tarefas (GET), que hoje é a principal ferramenta do premiado programa INSS Digital (Enap, 2018). O GET permite a gestão segura, eficiente e quantificável de fluxos de informação digital autenticada e rastreável entre diferentes atores internos (unidades orgânicas do próprio INSS) e externos (entidades parceiras que podem intermediar serviços do INSS). ${ }^{4}$

As apostas por trás do investimento foram: i) a tecnologia aplicada garantiria segurança e rastreabilidade dos processos; e ii) os custos transacionais reduzidos permitiriam inserir atores externos ao INSS na etapa inicial do processo de atendimento, sem necessidade de repasse financeiro. Vislumbrava-se então criar uma rede de atendimento por parcerias segura, eficiente e não onerosa, por meio de acordos de cooperação técnica (ACTs), em que os parceiros utilizariam um módulo externo de front-end do GET.

Tal proposta se alinha com relevantes teóricos da gestão colaborativa, ${ }^{5}$ que já apontavam para deficiências dos modelos tradicionais do movimento. Agranoff e McGuire (1999) insistiam que a gestão eficiente de serviços públicos em rede (network settings), apesar de prover agilidade, adaptabilidade e maior capacidade para inovação, dependeria do compartilhamento de objetivos entre as instituiçóes. No caso do INSS Digital, esse requisito é cumprido mandatoriamente em virtude da natureza do instrumento utilizado para a formalização das parcerias (ACT), em que não há contrapartida financeira envolvida.

Ainda, para os autores, a maior restrição enfrentada nos modelos de gestão colaborativa eram os elevados custos de comunicação entre parceiros. Mas essa restrição deve ser ponderada com o contexto da época, em que ainda náo existia a internet de forma plena, requisito fundamental na política do INSS (Agranoff e Mcguire, 1999).

McGuire (2006) alertava também para o "mito da colaboração": o valor intrínseco da ideia de colaboração, diante da competição inerente à new public management $(\mathrm{NPM})$, concedeu status de panaceia à gestão pública colaborativa, $\mathrm{o}$ que não se verificava na experiência empírica. Para o autor, a efetividade das redes de colaboração dependeria entâo de uma gestão superior centralizada na burocracia estatal, contradizendo a utopia hierarquicamente plana e auto-organizada. A proposta do INSS opera alinhada a essa preocupação: os parceiros trabalham como postos avançados e, portanto, não prescindem de quartéis-generais.

4. O GET foi efetivamente instituído enquanto sistema corporativo do INSS a partir da publicação da Portaria Pres/INSS no 91 , de 19 de janeiro de 2017, que autorizou a experiência-piloto do Projeto INSS Digital na GEX de Mossoró-RN (INSS, 2017). 5. Termo adaptado do original Collaborative Public Management (McGuire, 2006). Vários termos são aplicados ao fenômeno, a depender do enquadramento conceitual - e.g., network settings (Agranoff e McGuire, 1999), cross-sectoral partnerships (Andrews e Entwistle, 2010), redes/parcerias (Lotta, 2017), ou uma subcategoria de outsourcing (Schuppan, 2009; Bovaird, 2016). 
Por fim, Schuppan (2009) percebeu o potencial de impacto da TI sobre o desenho das redes de governança, em virtude de três princípios, identificáveis na proposta do INSS.

1) Modularização: o GET segrega o processo de prestação de serviços em módulos autônomos por etapa, ampliando as possibilidades de arranjos. Com essa lógica, é possível a restriçấo da atividade da entidade parceira àquelas funções não privativas do INSS, que envolvem menor discricionariedade.

2) Independência geográfica: o modelo permite que etapas do processo sejam cumpridas em diferentes unidades físicas do órgão, superando restrições de capacidade operacional local, com reduzidos custos transacionais, pois prescinde do deslocamento de processos ou pessoas.

3) Enriquecimento da Informaçấo: integrado o GET aos demais sistemas de atendimento, e sendo possível a mensuração de entradas e saídas em cada etapa dos processos, facilita-se a utilização de ferramentas de business intelligence (BI) e customer relationship management (CzRM) ${ }^{6}$

Sem contrapartida financeira, as parcerias seriam compensadas conforme o arranjo e sua natureza: sindicatos e associaçóes ampliariam contatos com filiados, fortalecendo sua legitimidade; entidades públicas subnacionais alavancariam economias locais com a aceleraçáo do pagamento de benefícios em seu território; e entidades filantrópicas agregariam a prestação de serviços do INSS ao seu portfólio.

A gestão colaborativa expandiria ainda a cobertura de direitos para além da estrutura instalada do INSS, alcançando regióes antes cobertas apenas por missóes esporádicas e atravessadores privados. Para além, seria possível prover serviços ao cidadão a partir de seu relacionamento preexistente com outras instituiçóes: prefeituras podem atrelar serviços do instituto a seus equipamentos; o trabalhador pode ser atendido ativa e diretamente pelo sindicato; e o idoso acolhido pode ser atendido pela própria entidade acolhedora.

Ocorre que, no final de 2014, antes da disponibilização de todas as ferramentas para a plena implementação da Política de Gestão Colaborativa, no cenário de contençáo fiscal, o INSS passou de forma repentina a responder pelo processamento do Seguro Defeso (Brasil, 2014b). ${ }^{7}$

6. Ferramentas de BI coletam e organizam informações para a tomada de decisão. CzRMs mapeiam pontos de contato da instituição com o cidadão, para compreender sua jornada e promover ações que antecipem/satisfaçam suas demandas. 7. Formalmente, os motivos para a transferência da competência de processamento do Seguro Defeso para o INSS não foram esclarecidos. A exposição de motivos da MP n 665, de 30 de dezembro de 2014, não justifica ou ao menos cita essa mudança de forma específica; entretanto, sinaliza o objetivo geral da norma de "tornar mais claro o enquadramento para fins de concessão do benefício pecuniário, diferenciando aqueles (pescadores) que vivem exclusivamente da pesca daqueles que exercem outras atividades profissionais" (Brasil, 2014b). É possível, portanto, inferir que a transferência objetivasse maior assertividade na concessão do benefício, o que, de fato, foi verificado (CGU, 2016). 
O Seguro Defeso é um benefício nascido da luta das organizaçóes representativas dos pescadores artesanais, com o objetivo de apoiar suas tecnologias de trabalho tradicionais contra a ameaça do crescimento da pesca industrial (Cardoso, 2001). Consiste em um valor de um salário mínimo mensal, pago aos pescadores a título de substituição de renda, durante os períodos anuais de proibição da atividade de pesca, conhecidos como defesos - ou seja, temporadas fechadas, geralmente para proteção das espécies em seu período de reprodução.

Uma série de estudos sobre os resultados da política revelou graves irregularidades e até mesmo indícios de fraudes, colocando o Seguro Defeso na mira da reforma fiscal inaugurada no final de 2014 pelas Medidas Provisórias (MPs) no 664 e 665 (Brasil, 2014b; 2014c). Naquele contexto, o INSS teria então o objetivo de, além de recepcionar e processar os requerimentos do benefício, adotar estratégias para reduzir as irregularidades detectadas (Caetano et al., 2015).

Com efeito, a partir de abril de 2015, o Seguro Defeso injetou um milhão de atendimentos anuais na esgotada rede do instituto. ${ }^{8}$ Mas se, por um lado, a chegada do Seguro Defeso acarretaria grande sobrecarga de atendimento, por outro, acabaria por abrir a grande janela de oportunidade para a Política de Gestão Colaborativa. Isso porque, para conter a nova demanda, dadas as restriçóes orçamentárias do período, o INSS foi forçado a lançar mão de novas estratégias de atendimento. Entre estas, optou-se pela implementação da gestão colaborativa, uma vez que, maciçamente, os pescadores artesanais são representados por entidades candidatas a parcerias em ACTs.

Contudo, o instituto ainda não contava com o suporte tecnológico adequado o GET estaria efetivamente disponível somente em 2017. Aplicar-se-ia então a modularização de Schuppan ainda de forma incipiente: o módulo de front-end, utilizado pelas entidades parceiras, seria "feito de papel", com remessa de formulários físicos ao INSS. Assim, de forma simplificada, a concessão do benefício ocorreria conforme o diagrama a seguir. ${ }^{?}$

8. Dado referente à demanda agregada de 2014, totalizada em 1.015.967 requerimentos. Fonte: Base de Gestão do Seguro-Desemprego, disponível em: <bi.mte.gov.br>.

9. Apesar de a política do Seguro Defeso envolver a atuação de diversos outros órgãos ao longo da trajetória do pescador, é representada no diagrama apenas a etapa que importa a este estudo - i.e., a concessão do benefício, que ocorre sob gestão do INSS. 
FIGURA 1

Fluxo de concessão do Seguro Defeso

Processo de concessão do SDPA - fase INSS

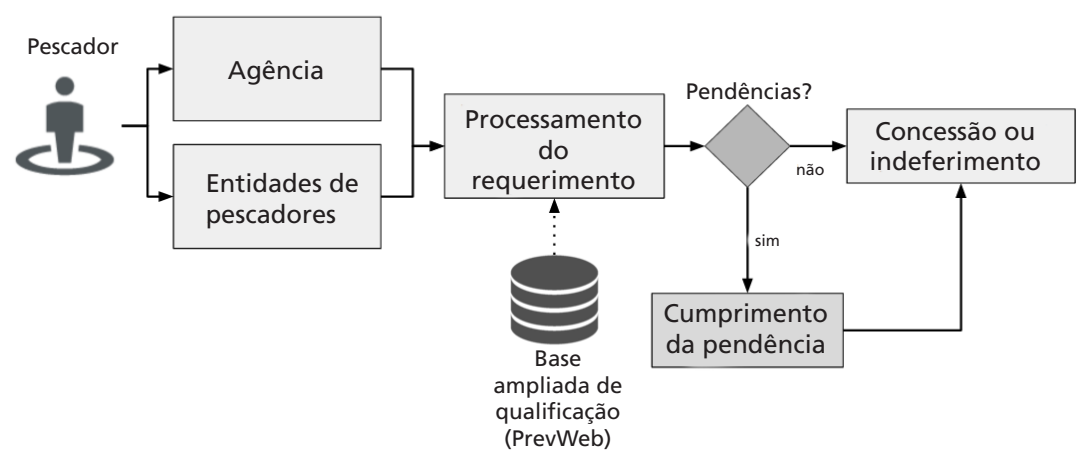

Fonte: Processo Administrativo 00190.103781/2016-79 da Controladoria-Geral da União (CGU, 2016).

Obs.: SDPA significa Seguro-Desemprego do Pescador Artesanal, nomenclatura legal do Seguro Defeso, mas pouco utilizada pelos operadores e destinatários da política.

De forma resumida, o pescador, atendido pela agência da Previdência Social (APS) ou pela entidade de pescadores, tem seu requerimento processado por servidores do INSS, utilizando a ferramenta PrevWeb, que disponibiliza o cruzamento de dados entre diferentes bases do governo. As informaçôes oriundas desses cruzamentos são confrontadas com aquelas prestadas pelo pescador em seu requerimento, para verificar as condiçóes de direito ao benefício. É solicitado o cumprimento de pendências se necessário, podendo o benefício ser concedido ou indeferindo pelo instituto (CGU, 2016; INSS, 2016). Quando o requerimento é originado nas entidades, temos representada a expressão da Política de Gestáo Colaborativa do INSS, sendo a modularização especificada por Schuppan (2009) manifestada, de forma incipiente (papel), na etapa de menor discricionariedade cumprida pelo parceiro.

Para o início da nova política, foi celebrado ACT com a Confederação Nacional de Pesca e Aquicultura (CNPA), ${ }^{10}$ representante da maioria das colônias de pesca (Cardoso, 2001; Silveira, 2011). Uma a uma, as demais entidades de pescadores também negociaram ACTs, e, ao longo de 2016, a maior parte dos requerimentos já seria processada em gestão colaborativa, colocando à prova o modelo idealizado.

O objetivo deste artigo é então avaliar o potencial da mudança de desempenho promovida pela Política de Gestão Colaborativa do INSS em 2016, sob a perspectiva de seu principal interessado, o pescador. Para tanto, será tratado o caso do Defeso do Camarão no sul da Bahia, abrangido pela Gerência-Executiva (GEX) do INSS, em Itabuna, ${ }^{11}$ para testar a seguinte hipótese:

10. Publicado na seção 3 do Diário Oficial da União (DOU) № 192, em 7 de outubro de 2015.

11. A GEX Itabuna, ou a GEX do INSS em Itabuna, é uma unidade da organização responsável pelas operações na região de Itabuna. 
H1: A Política de Gestão Colaborativa do INSS promoveu ganhos significativos de desempenho sob a perspectiva do pescador atendido pela GEX de Itabuna.

$\mathrm{O}$ artigo possui seis seções, incluindo-se esta introdução. A seção 2 demonstra a adequação do caso à avaliação pela metodologia de diferenças em diferenças, complementada por consideraçôes de natureza qualitativa. A seção 3 descreve o desenho da avaliação e os indicadores de desempenho adotados. A seção 4 detalha a metodologia aplicada e o cumprimento de suas premissas. A seção 5 registra os resultados quantitativos, comentados a partir dos achados qualitativos. A seção 6 conclui o trabalho, fornecendo críticas e recomendaçôes às estratégias adotadas pelo INSS, que podem ser úteis à implementação de modelos similares por outros órgãos.

\section{SELEÇÃO DO CASO}

O caso do Defeso do Camarão na GEX Itabuna apresenta combinação de três vantagens especialmente útil à aplicação do método de diferenças em diferenças (Angrist e Pischke, 2014), descritas a seguir.

Em primeiro lugar, verifica-se boa disponibilidade de dados dos beneficiários do Seguro Defeso, provenientes dos sistemas de BI do antigo Ministério do Trabalho e Emprego (MTE), hoje assimilado pelo Ministério da Economia (ME), e do INSS, e do Registro Geral da Atividade Pesqueira (RGP). As bases são relacionáveis pela inscrição do pescador no Cadastro de Pessoa Física (CPF). ${ }^{12}$

Em segundo lugar, temos que os defesos ocorrem em períodos anuais fixos, com duração de um a quatro meses, proibindo atividades pesqueiras em bacias hidrográficas, costas e estuários habitados pelas espécies protegidas. A demanda pelo seguro fica então restrita tanto no espaço quanto no tempo, o que, apesar de desafiar os procedimentos tradicionais da autarquia, ${ }^{13}$ facilita a avaliação de desempenho. Nesse sentido, o caso selecionado corresponde à primeira etapa do defeso do camarão no Nordeste, que atinge a costa e os estuários de Alagoas, de Sergipe e da Bahia, no período de $1^{\circ}$ de abril a 15 de maio, ${ }^{14}$ em 2015 e 2016 (Brasil, 2004).

12. Ver apêndice $A$.

13. Outros serviços do INSS não têm procura sazonal mandatória.

14. A Inscrição Normativa (IN) no 14/2004, do Ministério do Meio Ambiente (MMA), segrega o período de proibição da captura do camarão em duas etapas. A primeira etapa é comum a toda a região objeto do ato normativo, enquanto a segunda varia conforme a região, como demonstram os incisos do art. 1ำ do ato:

"Art. 1o Proibir, anualmente, o exercício da pesca de camarão rosa (Farfantepenaeus subtilis e Farfantepenaeus brasiliensis), camarão sete-barbas (Xiphopenaeus kroyeri) e camarão branco (Litopenaeus schmitti), com quaisquer artes de pesca, nas áreas e períodos abaixo discriminados:

I - na área compreendida entre a divisa dos Estados de Pernambuco e Alagoas e a divisa dos Municípios de Mata de São João e Camaçari no Estado da Bahia, nos períodos de 10 de abril a 15 de maio e 10 de dezembro a 15 de janeiro; II - na área compreendida entre a divisa dos Municípios de Mata de São João e Camaçari no Estado da Bahia e a divisa dos Estados da Bahia e Espírito Santo, nos períodos de 10 de abril a 15 de maio e de 15 de setembro a 31 de outubro" (Brasil, 2004, art. 1, grifos nossos).

Os pescadores das regiões abrangidas são atingidos pelas duas etapas da proibição e, portanto, fazem jus às parcelas do Seguro Defeso em ambos os períodos. 
Em terceiro, importa explicitar o motivo para a escolha da GEX de Itabuna. Com a celebração do ACT entre o INSS e a CNPA, em outubro de 2015, o INSS instruiu sua rede descentralizada a buscar a adesão ao ACT com as colônias filiadas à CNPA e propor também ACTs com entidades locais não filiadas (INSS, 2015b). ${ }^{15}$ Às GEXs do INSS caberia então articular redes de colaborativas de atendimento aos pescadores. No caso da GEX de Itabuna, sua rede de atendimento parceira não contemplou todos os pescadores em 2016, e, de 5.509 requerimentos, 1.683 foram recebidos ainda fisicamente nas agências da Previdência Social (APS). ${ }^{16}$ Precisamente, a possibilidade de segregação dessa amostra em grupos significativos de tratamento e controle (pescadores atendidos por ACT ou de forma convencional em 2016) torna o caso de Itabuna adequado à metodologia de diferenças em diferenças.

Apesar dos fatores favoráveis a uma análise quantitativa satisfatória, esta será ainda complementada com detalhes do processo do Seguro Defeso e entrevistas com atores relevantes no caso. A participação ostensiva do autor no desenho da política avaliada facilitou o acesso e a interpretação dos relatos, o que proporcionou maior profundidade à leitura dos resultados quantitativos.

Por fim, cumpre observar que a restrição do caso à GEX de Itabuna não compromete a relevância dos resultados, tanto em função das condiçóes ideais para a avaliação, como pelo impacto socioeconômico do Seguro Defeso na região de sua abrangência. A GEX de Itabuna organiza as atividades do INSS em toda a região do extremo sul e em parte do litoral sul da Bahia, que abrange integralmente as microrregióes Ilhéus-Itabuna e Porto Seguro, bem como o município de Maraú, totalizando 61 municípios sob sua influência. Destes, dezoito contêm todos os beneficiários do Seguro Defeso na região: Alcobaça; Aurelino Leal; Belmonte; Canavieiras; Caravelas; Ilhéus; Itabuna; Itacaré; Maraú; Mucuri; Nova Viçosa; Porto Seguro; Prado, Santa Cruz Cabrália; Ubaitaba; Ubatã; Una; e Uruçuca. A faixa destacada no mapa representa os territórios desses municípios, cuja população total é estimada em 967.049 pessoas (IBGE, 2017).

15. Atendendo a movimentos não reconhecidos pela CNPA, como o Movimento dos Pescadores e Pescadoras (MPP) e a Comissão Nacional de Fortalecimento das Reservas Extrativistas e dos Povos Extrativistas Costeiros Marinhos (Confrem), que não gozam do estatuto da CNPA, mas possuem relevância política e capacidade de mobilização.

16. Ver apêndice A. 
FIGURA 2

Litoral sul da Bahia

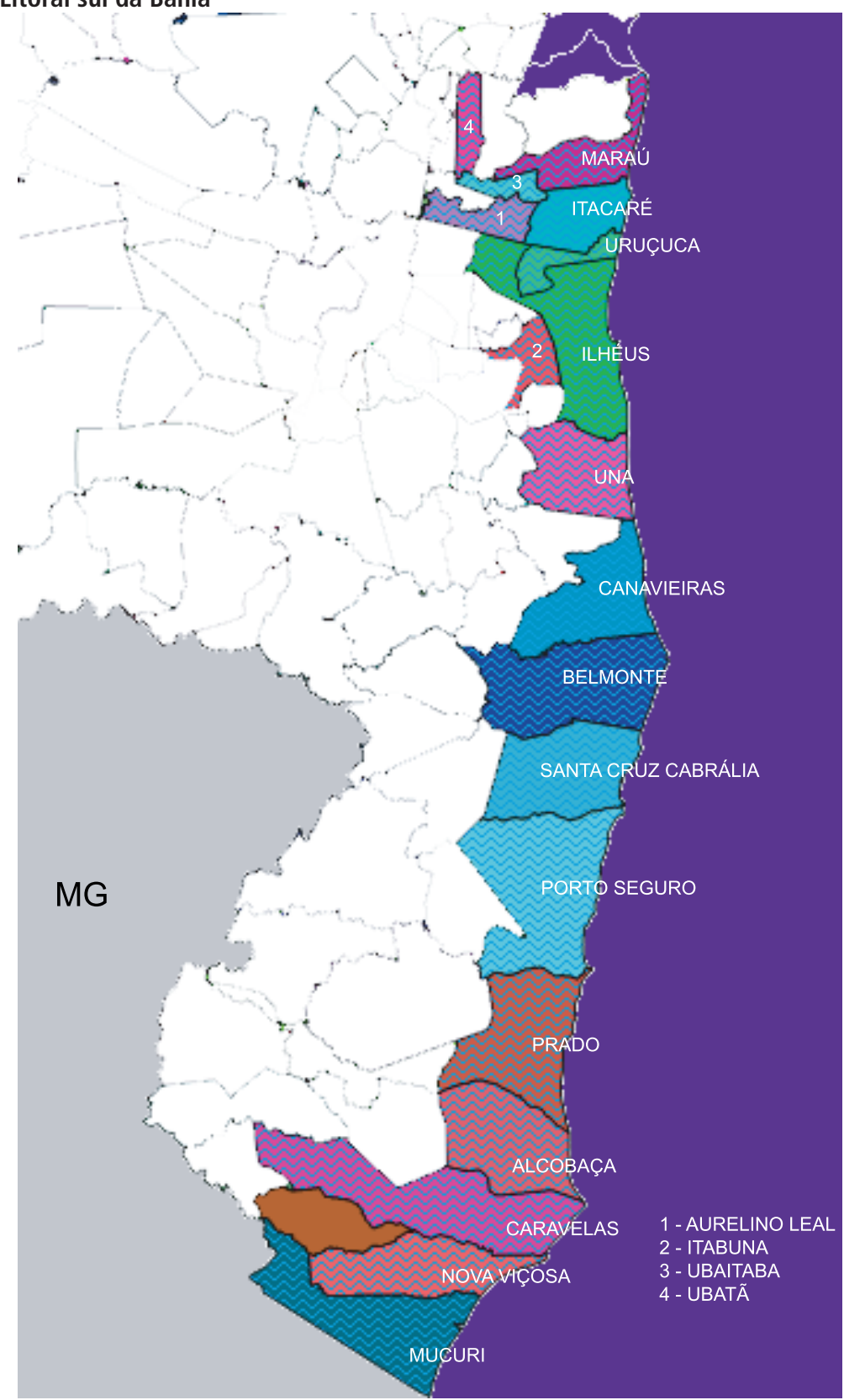

Elaboração do autor. 
Na região, 2.466 pescadores beneficiaram-se do Seguro Defeso continuamente em 2015 e 2016, ${ }^{17}$ representando pouco mais de $0,25 \%$ da população. Descontados municípios de demanda residual (Aurelino Leal, Itabuna, Ubatã, Una e Uruçuca), tal proporção sobe para $0,37 \%$. É razoável supor que parte substancial desses pescadores atua em regime de economia familiar, permitindo extrapolar o efeito do benefício a pelo menos três vezes a quantidade de beneficiários diretos. Deduz-se então que a operaçáo do Seguro Defeso na GEX Itabuna tem influência direta em 1\% da população da região, e, portanto, seus efeitos econômicos não podem ser desconsiderados.

Importa destacar ainda o perfil do pescador objeto da política. Nos termos da Lei no 10.779 , de 25 de novembro de 2003, o pescador que recebe o Seguro Defeso é aquele que náo dispóe de outra fonte de renda além da atividade pesqueira artesanal individual ou em regime de economia familiar, o que, inclusive, o caracteriza como segurado especial da Previdência Social, sujeito a contribuição previdenciária diferenciada (Brasil, 1991; 2003). Tal perfil é corroborado com aquele descrito em publicação organizada por Dias-Neto (2011), intitulada Proposta de Plano Nacional de Gestão para o Uso Sustentável de Camarôes Marinhos do Brasil: "(...) a pesca do camarão é atividade artesanal e hereditária - o pescador o é por seus pais e avós terem sido. É uma profissão a que a sociedade atribui pouca importância”. Essas características ampliam a relevância social do Seguro Defeso e corroboram as premissas da avaliação sob a dimensão da equidade ${ }^{18}$ (Andrews e Entwistle, 2010).

\section{DESENHO DA AVALIAÇÃO}

A avaliaçáo empreendida possui caráter formativo - ou seja, seu desenho visa auxiliar partes interessadas no desenvolvimento da política e na implementação de políticas similares (Weiss, 1998). Não cabe, portanto, atestar o sucesso ou o fracasso da política com base neste artigo, uma vez que: i) no período de análise, esta ainda não estava consolidada; $\mathrm{e}$ ii) indiferentemente aos achados, a política já foi aprovada e ampliada em 2017.

Apesar de formativa, a avaliação é focada no resultado, e não no processo, pois visa ao desempenho sob a perspectiva do destinatário da política, o pescador (Weiss, 1998). Essa categorizaçáo pode ser capciosa, pois o objeto é uma etapa do processo de implementação da política do Seguro Defeso - i.e., a habilitação pelo INSS; entretanto, a natureza da avaliação é relacionada a resultados dessa etapa, e não ao processo em si.

Ainda sob a luz da tipologia estabelecida por Weiss (1998), dado que a avaliação foi empreendida por servidor do INSS, possui natureza interna, o que traz vantagens e desvantagens. $\mathrm{O}$ autor participou da concepção e da implementação da política, o que, apesar do evidente risco de enviesamento: i) facilita a compreensão da teoria do programa; ii) facilita o manejo dos dados quantitativos; e iii) permite maior profundidade qualitativa nas análises e recomendaçóes.

17. Considerados apenas pescadores que necessariamente receberam o benefício nos dois anos; critério utilizado na seleção para avaliação.

18. Ver subseção 3.2 . 
Utilizando também o modelo estabelecido pela autora para compreensão da avaliação, temos que toda política envolve teorias da mudança: a teoria da implementação e a teoria do programa, que compóem cadeia causal deontológica, na qual, verificada cada etapa, a mudança deve ocorrer. Por exemplo, uma campanha contra o consumo do cigarro carrega a pretensão de, com suas atividades, promover mudanças de comportamento. Entendendo assim o programa/política como uma teoria, a avaliação é então seu teste empírico, a aferir, via indicadores, a adequação de cada etapa à realidade observada (Weiss, 1998).

As teorias da mudança da Política de Gestão Colaborativa são representadas no diagrama a seguir, em que, para cada etapa da direita (atividade que promove a mudança, atinente à teoria da implementação), corresponde uma etapa à esquerda (resultado, em conformidade à teoria do programa). Ou seja, em teoria, se cada atividade ocorrer da forma prevista, espera-se alcançar seu resultado correspondente, que, por sua vez, acarreta ou catalisa a execução da próxima atividade.

\section{FIGURA 3}

\section{Teorias da mudança ${ }^{1}$}

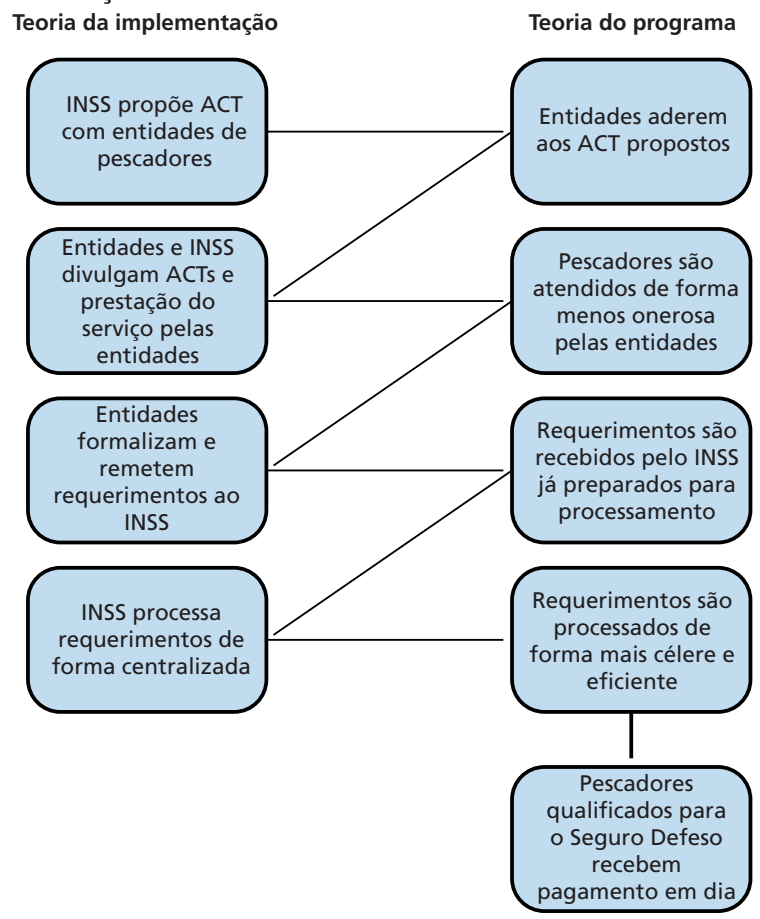

Elaboração do autor.

Nota: ${ }^{1}$ As entidades de pescadores são os agentes da segunda e da terceira etapa da teoria da implementação, o que caracteriza a natureza colaborativa da política. 
Dessa forma, o sucesso da Política de Gestão Colaborativa está atrelado à verificação dos resultados que compóem a teoria do programa, que devem pautar a escolha de indicadores para a análise quantitativa. Contudo, a gestão formal por indicadores do INSS não contempla a implementação do Seguro Defeso, apenas recentemente operacionalizado pela autarquia (Brasil, 2008). Fez-se necessário entáo desenvolver indicadores específicos para o caso, e, para tanto, foram selecionados critérios/dimensões ${ }^{19}$ de desempenho.

As dimensóes de desempenho utilizadas foram baseadas no modelo de avaliação proposto por Andrews e Entwistle (2010), sendo aproveitadas as dimensóes de efetividade e equidade, bem como descartada a dimensão da eficiência, por sua baixa relevância sob a perspectiva do pescador. Selecionadas as dimensôes, foram estabelecidas balizas conceituais (distinçôes), com o objetivo de traduzir os parâmetros abstratos da efetividade e da equidade no caso concreto, representadas na matriz a seguir (Andersen, Boesen e Pedersen, 2016).

QUADRO 1

Distinções para efetividade e equidade

\begin{tabular}{|l|l|l|l|}
\hline \multicolumn{1}{|c|}{ Distinção } & \multicolumn{1}{|c|}{ Pergunta } & \multicolumn{1}{|c|}{ Resposta } & \multicolumn{1}{c|}{ Motivação } \\
\hline 1. Partes interessadas & $\begin{array}{l}\text { Quem decide o que é bom } \\
\text { desempenho? }\end{array}$ & Pescadores & $\begin{array}{l}\text { Desempenho sob perspectiva do pescador } \\
\text { destinatário da política. }\end{array}$ \\
\hline 2. Formalidade & $\begin{array}{l}\text { Em que grau o desempenho } \\
\text { é definido formal ou infor- } \\
\text { malmente? }\end{array}$ & $\begin{array}{l}\text { Parcialmente } \\
\text { formal }\end{array}$ & $\begin{array}{l}\text { Apesar de não estabelecido formalmente, } \\
\text { os parâmetros de desempenho são deriva- } \\
\text { dos de comandos normativos. }\end{array}$ \\
\hline 4. Tipo do foco do processo & $\begin{array}{l}\text { Em que grau o desempenho } \\
\text { diz respeito a percepçães } \\
\text { internas em detrimento de } \\
\text { fenômenos externos? }\end{array}$ & $\begin{array}{l}\text { Majoritariamente } \\
\text { objetivo }\end{array}$ & $\begin{array}{l}\text { Qusponibilidade de dados e restrição de } \\
\text { investimento; utilizado material qualita- } \\
\text { tivo para complementação e crítica aos } \\
\text { resultados. }\end{array}$ \\
\hline 5. Tipo do foco do produto & $\begin{array}{l}\text { Que tipo de foco no produto } \\
\text { a dimensão tem? (e se tem) }\end{array}$ & $\begin{array}{l}\text { Quantificação } \\
\text { de resultados } \\
\text { (outcomes) }\end{array}$ & $\begin{array}{l}\text { Não tem } \\
\text { Sob perspectiva do destinatário da } \\
\text { política, o foco é no produto/resultado, } \\
\text { apesar da natureza de processo do objeto } \\
\text { da avaliação. }\end{array}$ \\
\hline 6. Unidades de análise & $\begin{array}{l}\text { Quem desempenha, e em } \\
\text { que nível? }\end{array}$ & $\begin{array}{l}\text { GEX do INSS de } \\
\text { Itabuna }\end{array}$ & $\begin{array}{l}\text { Disponibilidade de dados objetivos } \\
\text { relevantes e foco em resultados. }\end{array}$ \\
\hline
\end{tabular}

Elaboração do autor.

$\mathrm{Na}$ matriz, destaca-se que o pescador é o único interessado na avaliação (distinção 1), e exclusivamente enquanto destinatário da política, o que exclui do escopo dimensóes participativas/colaborativas. ${ }^{20}$ Nas próximas subseçóes, do processo de

19. Andrew e Entwistle (2010) intitulam essas categorias de desempenho de dimensões, termo que Andersen, Boesen e Pedersen (2016) substituem por critérios. Optou-se por manter o termo dimensões.

20. Mas, possivelmente, são afetados pelo tratamento. 
habilitação ao Seguro Defeso serão extraídos dois indicadores, correspondentes às duas dimensóes selecionadas, e serão objeto da aferição quantitativa.

Cumpre observar que a interpretação dos resultados quantitativos sobre as dimensóes selecionadas será complementada com informações do autor sobre o processo do Seguro Defeso, e com aquelas levantadas em: i) entrevista aberta com representantes de diferentes entidades e movimentos de pescadores da regiáo; e ii) questionário aberto respondido por cinco gestores locais do INSS por e-mail. Apesar do alcance restrito das entrevistas e questionários, os apontamentos dos participantes foram essenciais para a interpretação dos achados, como será demonstrado nas seçôes finais.

\subsection{Dimensão da efetividade}

A efetividade pode ser dada pelo grau em que a política alcança objetivos institucionais (Andersen, Boesen e Pedersen, 2016). Segundo Caetano et al. (2015), o Seguro Defeso possui dois objetivos: amparar financeiramente o pescador e proteger as espécies alvo da pesca durante o defeso. Entretanto, tais objetivos, situados além do escopo do INSS, não norteiam diretamente a avaliação. ${ }^{21}$

O objetivo institucional do INSS, subscrito na competência que lhe foi atribuída, pode ser definido como habilitar ao Seguro Defeso aqueles pescadores qualificados para seu recebimento (Caetano et al., 2015). Dado o objetivo, a efetividade a priori traduzir-se-ia no alcance da autarquia sobre os pescadores qualificados ao benefício e, portanto, poderia ser aferida pela quantidade de beneficiários habilitados.

Ocorre que, em oposição a esse vetor de efetividade, a transferência da competência ao INSS objetivou reduzir irregularidades da política (Campos e Chaves, 2014; Caetano et al., 2015), o que implicou, necessariamente, a redução das habilitaçóes ao seguro. Nesse sentido, verifica-se que, entre 2015 e 2016, de 72.999 requerentes, o número de benefícios concedidos reduziu-se de 70.022 para 37.249 - ou seja, foram excluídos do benefício cerca de $45 \%$ dos pescadores, mas não em função de queda de desempenho. ${ }^{22}$ Por sua vez, como explicitado no último item da teoria do programa, e dado o objetivo da política de substituir a renda do pescador durante o defeso, cabe ao INSS conceder o benefício tempestivamente, evitando atrasos que deixariam o pescador desamparado durante parte do período (Caetano et al., 2015).

Portanto, a efetividade do INSS, sob a perspectiva do pescador, pode ser verificada pela tempestividade no pagamento do benefício, sendo adequado aferi-la

21. 0 INSS é responsável apenas pela habilitação de beneficiários do Seguro Defeso (Brasil, 2014b), o que mal esgota a implementação do programa. 0 pagamento e a definição dos defesos estão fora de sua gestão.

22. Fonte: Base de Gestão do Seguro-Desemprego. Disponível em: <bi.mte.gov.br>. 
então pela proporção de pescadores que receberam o benefício de forma tempestiva, em que o denominador deve ser o total de pescadores que receberam o benefício. Isto porque não é possível verificar quantitativamente, entre os demais pescadores, aqueles que seriam destinatários legítimos do Seguro Defeso.

É necessário então caracterizar o recebimento tempestivo. De forma coerente com a natureza do benefício, é adequado o critério do $\$ 1^{\circ}$ do art. 459 da Consolidação das Leis Trabalhistas (CLT): o pagamento do empregado deve ocorrer até o quinto dia útil do mês subsequente ao vencido (Brasil, 1943). Mas, dada a variação inerente ao prazo, por ser contado em dias úteis, e a falta de governança sobre o pagamento após a habilitação ao benefício, entender-se-á como tempestivo aquele pagamento disponibilizado até o décimo dia do mês subsequente ao primeiro mês do defeso que deu origem ao benefício. ${ }^{23}$

Definimos entâo o indicador de efetividade como o percentual de beneficios concedidos com pagamento disponivel até o décimo dia do segundo mês do defeso (maio). ${ }^{24}$

\subsection{Dimensão da equidade: cobertura}

O conceito para representar a dimensão da equidade embute uma forma de eficiência sob a perspectiva do pescador, pois se refere, indiretamente, à variação do seu custo para acesso ao benefício. Nesse sentido, uma premissa estabelecida na teoria do programa é de que, com a gestão colaborativa, a cobertura espacial do INSS aumenta, reduzindo o deslocamento do pescador para requerer o benefício, dada a maior proximidade física e institucional entre ele e as entidades. A redução das distâncias percorridas é convertida em redução dos custos imputados ao pescador, geralmente hipossuficiente, o que acarreta maior relevância do impacto na dimensão da equidade.

A mensuração da variação nas distâncias percorridas é possível devido à disponibilidade de dados, tanto da residência do pescador beneficiário, como da localização das APS e das entidades, na granularidade de CEP. ${ }^{25}$

Estabelecemos assim o indicador de equidade/cobertura, que será a média das diferenças em quilômetros entre a distância percorrida pelo pescador da região de sua

23. 0 atraso no processamento pelo INSS reflete-se apenas no primeiro pagamento. Sendo disponibilizado em dia, os seguintes o serão também, sem influência da Autarquia em sua tempestividade.

24. Ver apêndice $A$.

25. A relação das entidades signatárias foi fornecida por Fritz Rocha, servidor da Seção de Atendimento da GEX de Itabuna, que, à época do caso, respondia pela organização do atendimento aos pescadores: i) filiados à CNPA: Z 18 Itacaré, Z 19 - Ilhéus, Z 20 - Canavieiras, Z 21 - Belmonte, Z 21 - Canavieiras, Z 23 - Prado, Z 22 - Porto Seguro, Z 34 - Ilhéus, Z 35 - Mucuri, Z 68 - Ubaitaba e Z 89 - Aurelino Leal, Associação das Marisqueiras do São Miguel - Ilhéus e Associação dos Marisqueiros Aquicultores e Pescadores de Nova Viçosa - Nova Viçosa; e ii) não filiados à CNPA: Z 18 - Ilhéus e Z 24 - Alcobaça. 
residência à região da entidade representativa mais próxima e a distância da regiäo de sua residência à regiáo da APS mais próxima. ${ }^{26}$

O quadro 2 sintetiza os indicadores, atribuindo termos utilizados na avaliação.

QUADRO 2

Resumo de indicadores

\begin{tabular}{|l|l|l|l|}
\hline \multicolumn{1}{|c|}{ Indicadores } \\
\hline \multicolumn{1}{|c|}{ Dimensão } & \multicolumn{1}{|c|}{ Enunciado } & Termo & \multicolumn{1}{c|}{ Unidade } \\
\hline Efetividade & $\begin{array}{l}\text { Percentual de benefícios concedidos com pagamento } \\
\text { disponível até 10 de maio. }\end{array}$ & benpontual & $\%$ \\
\hline $\begin{array}{l}\text { Equidade } \\
\text { (cobertura) }\end{array}$ & $\begin{array}{l}\text { Média das diferenças em quilômetros entre as distâncias } \\
\text { percorridas pelo pescador até o local de requerimento. }\end{array}$ & distmedia & $\mathrm{Km}$ \\
\hline
\end{tabular}

Elaboração do autor.

\section{METODOLOGIA}

O método utilizado para a aferição do impacto foi de diferenças em diferenças. Dados dois grupos, um de controle (cont) e outro de tratamento (trat, que sofreu a intervenção/tratamento estudado), e dois momentos, um anterior e outro posterior ao tratamento $(t 1$ e $t 2)$, o método diferenças em diferenças presume que, subtraída a diferença $t 2-t 1$ de cont da diferença $t 2-t 1$ de trat, o resto corresponde ao efeito do tratamento.

Porém, essa presunção decorre da premissa das "tendências comuns": sem tratamento, a evolução de trat corresponderia à evolução de cont. Ou seja, os dois grupos evoluiriam no tempo da mesma forma (Angrist e Pischke, 2014). As três condiçóes descritas nas subseçôes a seguir validam a premissa das tendências comuns.

1) Registros fixos no tempo: a identificação dos registros por chave única (CPF) possibilitou constituir grupos fixos, de composiçáo constante no tempo. Os pescadores que constituem cada grupo (trat e cont) não mudam do momento $t 1$ (defeso de 2015) para o momento $t 2$ (defeso de 2016); isso implica que as observaçóes em $t 1$ e $t 2$ são relativas aos mesmos registros. Essa característica garante que variáveis não observáveis relacionadas à composição dos grupos se mantenham estáticas.

2) Mesma unidade regional (GEX): Ao restringir a amostra à GEX de Itabuna, garantimos que a política esteve sob a mesma gestão em cont e trat, e, assim, variáveis não observáveis são impactadas por choques e ações de gestâo regionais de forma uniforme em ambos os grupos. 
3) Mesmas unidades locais (APS): Como cada elemento de cont é, nos momentos $t 1$ e $t 2$, atendido por uma mesma APS, será submetido aos mesmos choques e às mesmas decisôes gerenciais locais - i.e., em nível de APS. Isso também vale para o contrafactual em trat. se os pescadores fossem atendidos no modelo tradicional em $t 2$, seriam acolhidos pelas mesmas APS de $t 1$.

Entretanto, apesar da constância das variáveis concernentes à gestão local em relação a cada elemento no tempo, náo podemos inferir isso para os grupos. Isto porque os grupos não compartilham da mesma proporção de municípios de residência e, consequentemente, de APS de atendimento, tornando necessária a utilização de variáveis de controle específicas. Regressóes lineares multivariadas com variáveis de controle permitem melhor separar, do efeito do tratamento, impactos de outras variáveis observáveis no método diferenças em diferenças (Gertler et al., 2015). Nesse sentido, foram acrescentas ao cálculo variáveis básicas dos pescadores, controlando a estimativa por gênero (dummy), idade e tempo de inscrição no RGP, além da APS de processamento, por meio de variáveis dummy para cada APS:

$Y=\alpha_{1} A P S_{1}+\alpha_{2} A P S_{2} \ldots+\alpha_{n} A P S_{n}+\beta_{0}+\beta_{1}$ post $+\beta_{2}$ trat $+\beta_{3}$ post $*$ trat $+\varepsilon$.

Amplia-se assim a significância dos resultados, além de fortalecer a premissa de tendências comuns, isolado o impacto de fatores atrelados às APS de processamento.

\section{RESULTADOS}

Preliminarmente, cumpre registrar que foi verificada influência significativa de outliers na amostra: 91 pescadores $(3,7 \%)$ possuem datas de habilitação no ano seguinte ao do defeso, seja em $t 1$ ou em $t 2$, distorcendo significativamente os resultados na dimensão da efetividade - i.e., apesar de serem relativamente poucos registros, o tempo de espera para o pagamento nesses casos superou trezentos dias. Com vista a manter a integridade da condição de registros fixos no tempo, todos os outliers foram excluídos, independentemente de a data de habilitação ser distorcida apenas em $t 1$ ou apenas em $t 2 .{ }^{27}$

Verificou-se duas características notáveis nos outliers: i) dos 91 requerimentos, 84 foram processados na APS Prado; e ii) 77 foram habilitados entre 20 de junho de 2017 e 12 de julho de 2017. O gestor técnico daquela unidade, Juliano Cezar da Silveira Almeida, esclareceu que a causa foram divergências na interpretação das regras de concessão. Pelos normativos então vigentes, o INSS cessaria benefícios quando detectada “(...) obtençáo de renda proveniente da pesca de espécies 
alternativas não contempladas no ato que fixar o período de defeso" (INSS, 2015a, art. 10, inc. III).

Ocorre que o RGP dos pescadores com habilitação atrasada em Prado informava mais de um tipo de pesca, geralmente peixes e crustáceos. ${ }^{28}$ A APS de Prado interpretou então que, licenciado para capturar dois tipos de pesca, o pescador não faria jus ao benefício, uma vez que dispóe de alternativa de pesca. Tal interpretação perdurou até julho de 2017, quando a GEX de Itabuna a adequou ao sentido largamente aplicado no INSS, de que o pescador licenciado para diferentes tipos de pesca não necessariamente explora comercialmente todos estes, acarretando a habilitação tardia aos benefícios.

Compreendidos e excluídos os outliers, as subseçôes seguintes e a seção final descrevem os resultados quantitativos, relacionando-os com as informações de natureza qualitativa.

\subsection{Impacto sobre efetividade}

Houve ampliação significativa da tempestividade dos pagamentos.

\section{TABELA 1}

Efeito na tempestividade do pagamento (benpontual) (2015 e 2016)

(Em \%)

\begin{tabular}{lc}
\hline $\mathrm{t} 1(2015)$ & benpontual \\
\hline cont & 79 \\
trat & 67 \\
dif(cont-trat) & 12 \\
\hline $\mathrm{t} 2(2016)$ & benpontual \\
\hline cont & 16 \\
trat & 28 \\
dif(cont-trat) & -12 \\
dif em dif & 24 \\
\hline
\end{tabular}

Elaboração do autor.

Obs.: $R^{2}$ : 0.35; e.p. 0,$028 ; p<0,01$.

A gestão colaborativa incrementou em $24 \%$ a tempestividade, rejeitando a hipótese nula para significância de $1 \%$. O valor de $R^{2}$ em $35 \%$ permite dizer que o modelo explica $35 \%$ da variância - i.e., as variáveis em estudo são responsáveis por mais de um terço do efeito na tempestividade de pagamento. Quanto à teoria do programa, o incremento na tempestividade demonstra a adequação da terceira, quarta e quinta etapas: i) os requerimentos foram preparados antecipadamente para 
processamento; ii) uma vez previamente preparados, são processados de forma mais eficiente; e iii) os pescadores são pagos tempestivamente.

Os relatos dos gestores do INSS à frente do processamento em 2015 e 2016 corroboram o achado. Segundo Robson Carvalho de Oliveira, da APS Canavieiras:

A ausência dos segurados na APS possibilitou uma melhor qualidade na análise dos processos, melhorando a produtividade, visto que, quando o atendimento era presencial, a APS esteve frequentemente cheia, o que provocava mais cansaço nos servidores e dificuldade de concentraçáo, devido a barulho e interrupçáo frequente dos segurados na linha de frente. ${ }^{29}$

Para Moisés Rodrigues de Oliveira Filho, na APS Belmonte:

A intermediação da entidade representativa otimiza a organização do fluxo, bem como facilita a padronização dos documentos essenciais e, por fim, potencializa a difusão das informaçóes que podem ser dadas em bloco através de reunióes ou de informativos enviados diretamente para a entidade. Conseguimos aqui na APS de Belmonte - atendendo Belmonte e Sta. Cruz Cabrália - que mais de 90\% dos cerca de mil pescadores não tenham tido a necessidade de comparecer à APS. Consideramos fundamental a parceria com as entidades representativas locais. ${ }^{30}$

Isaac Lima Rocha, da APS Caravelas, relata que

Com o ACT, a análise e a conclusáo do processo passaram a ser feitas sem a presença do requerente. Isso foi uma grande vantagem, já que, em 2015, quando não havia ACT, a agência ficava cheia de pescadores, inclusive muitos sentados no chão esperando por mais de três horas para ser atendidos. ${ }^{31}$

Por sua vez, Anselmo Tadeu Vilas Boas da Silva, também da APS Caravelas, concorda com a melhoria, mas registra preocupação com a segurança:

Como impacto positivo, tivemos a redução considerável no fluxo de pescadores para requerimento do SDPA na APS, que facilitou a realizaçáo das atividades; como impacto negativo, percebemos que ficou diminuída a possibilidade de identificação de terceiros que poderiam se passar por pescadores, com a finalidade de acesso ao benefício. ${ }^{32}$

Questóes relacionadas a irregularidades ou fraudes na concessão do benefício não são objeto desta avaliação; entretanto, cabe abordar a preocupação exposta à luz do processo da concessão do benefício de forma integral. O pescador artesanal objeto da política é previamente identificado pelo órgáo competente para a organização da atividade pesqueira, à época, o Ministério da Pesca e Aquicultura (MPA), responsável, portanto, pela manutenção do cadastro do RGP. Ainda, no

29. Entrevista com o autor, em 23 de janeiro de 2018.

30. Idem.

31. Idem.

32. Entrevista com o autor, em 24 de janeiro de 2018. 
momento do saque do benefício, o pescador é novamente identificado pela rede bancária da Caixa Econômica Federal (Caixa). Ou seja, o problema concernente à identificação do pescador é mitigado, dado que apenas o pescador previamente inscrito no RGP faz jus ao benefício, e que, quando do efetivo recebimento de valores, o agente pagador é responsável por identificar o recebedor (CGU, 2016).

Por fim, na visão de Raquel Silva Neto, servidora que participou do atendimento em 2015 e 2016, "não há superlotação da APS e nem agenda impactada. O processamento se restringiu à consulta e à análise do direito, sem outras demandas como autenticação de documentos". ${ }^{33}$

\subsection{Impacto sobre equidade: cobertura}

A análise do impacto sobre equidade é mais simples, pois em $t 1$ para trat, e a qualquer tempo para cont, não há alternativa de atendimento à APS mais próxima da residência do pescador. Por sua vez, para trat em $t 2$, há necessariamente mais alternativas, pois nada impede que esses pescadores optem pela APS ou entidade mais próxima de sua residência. Logo, o controle de variáveis não observáveis acabou por tornar-se desnecessário, como sugerem os resultados.

TABELA 2

Efeitos na cobertura (indicador distmedia) (2015 e 2016)

(Em km)

\begin{tabular}{lc}
\hline $\mathrm{t} 1(2015)$ & distmedia \\
\hline cont & 31,31 \\
trat & 39,44 \\
dif(cont-trat) & $-8,13$ \\
\hline $\mathrm{t} 2(2016)$ & distmedia \\
\hline cont & 31,31 \\
trat & 19,66 \\
dif(cont-trat) & 11,65 \\
dif em dif & $-19,78$ \\
\hline
\end{tabular}

Elaboração do autor.

Obs.: R2: 0.33; e.p. 1,991; $p<0,01$.

A política proporcionou então avanços na dimensão da equidade, reduzindo custos para o pescador. A média de quase $20 \mathrm{~km}$ de redução da distância atesta com segurança a relevância do ganho proporcionado. O presidente da Federação das Associaçôes da Reserva Extrativista Marinha do Corumbau, José Conceição Jesus, fortalece essa conclusão: apesar de sua entidade não ser signatária de ACT,

33. Entrevista com o autor, em 23 de janeiro de 2018. No âmbito da política proposta, os documentos passaram a ser autenticados por advogado da entidade, dispensando o servidor dessa atribuição. (INSS, 2015b; 2016). 
ele reconhece o maior desafio do Seguro Defeso na distância entre órgãos públicos e pescadores. ${ }^{34}$

Entretanto, em entrevistas com outros representantes, são apresentados indícios que relativizam os ganhos de equidade. Segundo José Raimundo Assunção da Conceição, associado à colônia não signatária z-62 de Maraú, o atendimento pelas entidades envolve a "questáo política", sobre a qual não foram fornecidos detalhes. ${ }^{35} \mathrm{O}$ pescador pode estar se referindo à utilização política do poder de intermediação das entidades.

Nesse mesmo sentido, Gilmar Jesus de Souza, de Porto Seguro, filiado à Associação dos Pescadores e Moradores da Aldeia do Bugigão - entidade não signatária de ACT -, descreve formas de capitalização do serviço por colônias signatárias. Segundo ele, enquanto sua associação participa do cotidiano dos pescadores indígenas da Aldeia, a colônia (signatária do ACT) "só visa o lucro", cobrando imposto sindical e mensalidade, além de taxa que varia entre $\mathrm{R} \$ 180,00$ e $\mathrm{R} \$ 220,00$, com objetivo de "aquisição" da inscrição no RGP. ${ }^{36}$

José Conceição Jesus, já citado, detalha mais o que seria o modus operandi das colônias. Segundo ele, quando os atos relativos ao Seguro Defeso são feitos por entidades, o pescador fica refém, pois estas cobram, além das taxas sindicais, tarifas mensais relacionadas indiretamente à prestação do serviço. Não há obrigação expressa, mas a recusa do pagamento acarretaria ameaça; náo prosperando a ameaça, a entidade propositalmente descumpre prazos com os órgãos - e.g., para renovação do RGP ou requerimento de Seguro Defeso. ${ }^{37}$

Ainda que a etapa inicial do processo não envolva ampla discricionariedade, é inegável que envolve alguma. Como demonstram os autores da chamada sociologia do guichê, em diversas situaçóes de prestação de serviço público por entidades da sociedade civil ocorre o fenômeno da "estatização": operadores adotam posturas e práticas similares àquelas dos servidores públicos oficiais, e, assumindo maior discricionariedade em suas atividades, decidem pela exclusão ou inclusão dos usuários da política, cobertos pelo "manto" da legitimidade estatal outorgada (Pires, 2016).

Há indícios desse comportamento nas entrevistas. E a legitimidade de obrigaçóes impostas pela entidade para acesso ao benefício pode passar inquestionada, pois, para o pescador, aquela instância representa o Estado. No caso, o fenômeno é particularmente forte, dados os antecedentes históricos das colônias - i.e., foram constituídas como órgáos da Marinha (Cardoso, 2001).

34. Entrevista com o autor, em 24 de janeiro de 2018.

35. Entrevista com o autor, em 23 de janeiro de 2018.

36. Idem. O registro no RGP é gratuito.

37. Idem. 
As narrativas apresentadas devem ser consideradas na dimensão da equidade. Pois a intermediação da entidade pode impor ao pescador ônus invisíveis à gestão, independentemente do mérito ou da legalidade dos procedimentos das entidades ou seja, irregulares, nos casos de contrapartidas financeiras/políticas exclusivamente vinculadas à concessão do benefício; ou legais/legítimos, nos casos da cobrança de imposto sindical, mensalidade de associação, ou outras taxas que, se não quitadas, poderiam implicar a suspensão da filiação e, consequentemente, o impedimento da representação pela entidade.

\section{CONCLUSÕES}

A tabela 3 sintetiza os efeitos estimados da gestão colaborativa no desempenho da habilitação ao Seguro Defeso.

\section{TABELA 3}

\section{Efeitos da gestão colaborativa}

\begin{tabular}{llcc}
\hline Dimensão & \multicolumn{1}{c}{ Indicador impactado (enunciado) } & Efeito médio estimado & e.p. \\
\hline Efetividade & $\begin{array}{l}\text { Benefícios concedidos com pagamento disponível até } \\
10 \text { de maio }(\%)\end{array}$ & $+24,9$ & $2,3^{(1)}$ \\
Equidade (cobertura) & $\begin{array}{l}\text { Média das diferenças entre as distâncias percorridas pelo } \\
\text { pescador até o local de requerimento }(\mathrm{Km})\end{array}$ & $-19,78 \mathrm{~km}$ & $2^{(1)}$ \\
\hline
\end{tabular}

Elaboração do autor.

Nota: ${ }^{1} p<0,01$

Com o que foi observado e comentado em decorrência direta da avaliação, as próximas subseçôes consideram as entrevistas com atores do caso, as conclusóes da literatura e a experiência do autor para propor alternativas de evolução da política. Cabe considerar, entretanto, que hoje a Política de Gestão Colaborativa do INSS se encontra consolidada e em expansão, como pode ser verificado, por exemplo, em publicaçôes do portal do instituto na internet (INSS, 2019). Dessa forma, algumas das elaboraçóes a seguir podem ter perdido seu objeto, uma vez que são derivadas da experiência restrita ao Seguro Defeso em 2016.

\subsection{Qualidade do atendimento dos parceiros}

Os indicadores utilizados, ainda que relevantes nas dimensôes propostas, não são eficazes em sintetizar todos os aspectos da qualidade do atendimento aos pescadores. Por exemplo, implicitamente, o modelo presume melhorias de qualidade no atendimento, a partir de um mecanismo de representatividade burocrática, uma vez que, sendo os pescadores atendidos por seus pares, seriam esperados ganhos de qualidade (Costa, Alves e Gomes, 2016).

Entretanto, ilustrando o fato oposto à teoria, José Raimundo Assunção da Conceição, representante da colônia z-62 de Maraú, entende que o acesso é mais 
fácil no INSS, pois na colônia é "muita gente de uma vez só, em um dia só, pois não tem agendamento". ${ }^{38} \mathrm{~A}$ narrativa ressalta a necessidade de atentar ao tratamento dispensado pelas entidades ao pescador.

Essa atenção pode ser materializada na forma de mecanismos de monitoramento das condiçóes de atendimento nas entidades, como: i) pesquisas de satisfaçáo; ii) indicadores para avaliação da etapa executada pelos parceiros; ou iii) fiscalização, que, para não sobrecarregar o INSS, pode ser acionada por gatilhos instalados nos sistemas de monitoramento do atendimento já existentes ${ }^{39}$ e/ou padróes observados na ouvidoria-geral competente.

\subsection{Facilitação do processo de parceria}

Os representantes Gilmar Jesus de Souza e José Conceição Jesus relataram entraves burocráticos à celebração dos ACT, questão corriqueiramente verificada na realização de parcerias entre os órgãos públicos e o terceiro setor. Essa restrição pode ser mitigada com o ganho de experiência do INSS na celebração dos acordos, padronizando e simplificando procedimentos em suas instâncias administrativas e jurídicas. Como alternativa, para além dos ACTs, pode ser desenvolvido mecanismo universal de adesão, como aquele que contempla as entidades filiadas à CNPA (INSS, 2015b).

Ainda, para uma etapa restrita de baixa discricionariedade como a recepção e a digitalização de requerimentos, sem contrapartida onerosa, talvez instrumentos complexos possam ser dispensados. Procuraçóes individuais eletrônicas, nas quais a entidade intermediária registra a vontade do pescador de ser representado, independentemente de sua filiaçáo, poderiam substituí-los. Tais ferramentas podem combater também o que foi relatado por José Conceição de Jesus: $\mathrm{O}$ pescador "refém" da entidade, uma vez que, dispensada a filiaçáo, os pescadores poderiam "migrar" de entidade de filiação conforme: i) a legitimidade de representação; ou ii) o melhor atendimento.

\subsection{Ampliação das parcerias a entidades de diferentes naturezas}

Sem prejudicar o pré-requisito de parceiros com objetivos compartilhados, é factível firmar parceiras com entidades de natureza diversa, ampliando-se as opçóes de intermediários ao pescador, o que pode melhorar a qualidade do atendimento (Agranoff e McGuire, 1999). Ainda que isso não implique "competição" pelo atendimento ao pescador, pelo menos seus deslocamentos poderiam ser reduzidos com a ampliação das opçôes.

38. Entrevista com o autor, em 23 de janeiro de 2018.

39. Implementado o GET, a interação entre parceiros e INSS é eletrônica, com a efetiva modularização preconizada por Schuppan, e a possivel aplicação de ferramentas de BI/CZRM às informações fornecidas por parceiros. 
Outros órgãos e entidades representativas, como governos municipais, estaduais, Marinha, superintendências federais da pesca e aquicultura (SFPAs) e associaçóes podem ter interesse na parceria, se configurados mecanismos de compensação não onerosa/indireta pela prestação. Importa ressaltar que, apesar da legítima representatividade da categoria pelas entidades de pescadores, ${ }^{40} \mathrm{a}$ administração pública e, portanto, o INSS possuem a faculdade de celebrar ajustes não onerosos na forma de ACTs, seja com outras entidades da administração pública, seja com entidades privadas sem fins lucrativos, desde que visem aos seus objetivos institucionais (AGU, 2013).

Enfim, a maior disponibilidade de intermediários tende a reduzir os "ônus invisíveis" e a refenização do pescador. Entretanto, ressalta-se que a ampliação "indiscriminada" de parcerias pressupóe que as ferramentas tecnológicas reduzam os custos de transação (Schuppan, 2009).

\subsection{Futuro: disponibilidade de capacidade residual}

É importante o INSS atentar para a necessidade de garantir capacidade residual de operação independentemente de parceiros (Bovaird, 2016), evitando o hollow-out, que o tornaria refém de futuros "cartéis de entidades"; risco que McGuire prevê com o "mito da colaboração" (McGuire, 2006). E é preciso atentar também ao termo "residual": a estrutura "colossal" instalada do instituto já é residual diante das dimensões do Brasil.

Conclui-se por fim que, apesar dos sucessos da gestão colaborativa, é fundamental "levantar o tapete". A narrativa da possível capitalização da intermediação pelas entidades, apesar dos comandos normativos no sentido oposto, combinada com a "estatização" da postura de seus agentes, pode deslegitimar a política, distorcendo o princípio dos objetivos compartilhados.

No entanto, náo é razoável supor que tais mecanismos sejam disparados somente quando da formalização das parcerias. E se a gestáo colaborativa arrisca fortalecer justamente esses mecanismos, também os expôe à luz à medida que são incluídos formalmente no processo. Afinal, é senso comum que, em larga escala, o atendimento do INSS já é agenciado por intermediários individuais ou organizados, cujos objetivos raramente são compartilhados com os da autarquia. Sob os procedimentos convencionais, esses agentes permanecem fora de qualquer controle, seja exercido pela sociedade, seja pelo governo.

40. Seja mandatória, no caso dos sindicatos reconhecidos e das colônias, nos termos da Lei no 11.699, de 13 de junho de 2008 (Brasil, 2008), seja de fato, no caso das associações ligadas a movimentos sociais. 


\section{REFERÊNCIAS}

AGRANOFF, R.; MCGUIRE, M. Managing in networking settings. Review of Policy Research, v. 16, n. 1, p. 18-41, 1999.

AGU - ADVOCACIA-GERAL DA UNIÁO. Parecer da Câmara Permanente de Convênios/Depconsu/PGF/AGU no 15 , de 2 de dezembro de 2013. Temas relacionados a convênios e demais ajustes congêneres tratados no âmbito da Câmara Permanente de Convênios designada por meio da Portaria/PGF no 98, de 26 de fevereiro de 2013. Câmara Permanente de Convênios - CPCV, Brasília, 24 maio 2013. Disponível em: <https://bit.ly/2L4X2LX>. Acesso em: 3 abr. 2017.

ANDERSEN, L. B.; BOESEN, A.; PEDERSEN, L. H. Performance in public organizations: clarifying the conceptual space. Public Administration Review, v. 76, n. 6, p. 852-862, 2016.

ANDREWS, R.; ENTWISTLE, T. Does cross-sectoral partnership deliver? An empirical exploration of public service effectiveness, efficiency, and equity. Journal of Public Administration Research and Theory, v. 20, n. 3, p. 679-701, 2010.

ANGRIST, J. D.; PISCHKE, J.-S. Mastering 'metrics: the path from cause to effect. New Jersey: Princeton University Press, 2014.

BOVAIRD, T. The ins and outs of outsourcing and insourcing: what have we learnt from the past 30 years? Public Money \& Management, v. 36, n. 1, p. 67-74, 2016.

BRASIL. Decreto-Lei no 5.452, de 1o de maio de 1943. Aprovação a Consolidação das Leis do Trabalho - CLT. Diário Oficial da República Federativa do Brasil, Brasília, p. 11.937, 9 ago. 1943. Seção 1. Disponível em: <https://bit.ly/2I5R8ca>. Acesso em: 3 fev. 2018.

. Lei no 8.212, de 24 de julho de 1991. Dispóe sobre a organização da seguridade social, institui plano de custeio, e dá outras providências. Diário Oficial da República Federativa do Brasil, Brasília, 25 jul. 1991. Seção 1. Disponível em: <https://bit.ly/2L8FDCd>. Acesso em: 30 mar. 2019.

. Lei no 10.779 , de 25 de novembro de 2003. Dispóe sobre a concessão do benefício de seguro-desemprego, durante o período de defeso, ao pescador profissional que exerce a atividade pesqueira de forma artesanal. Diário Oficial da Uniáo, Brasília, p. 1, 26 nov. 2003. Seção 1. Disponível em: <https://bit. ly/31JrW9q>. Acesso em: 30 mar. 2019.

Ministério do Meio Ambiente. Instrução Normativa MMA no 14, de 14 de outubro de 2004. Diário Oficial da União, Brasília, p. 76, 15 out. 2004. Seção 1. Disponível em: <https://bit.ly/3mEuqXF>. Acesso em: 3 fev. 2018. 
. Lei no 11.699, de 13 de junho de 2008. Dispóe sobre as colônias, federações e a Confederação Nacional dos Pescadores, regulamentando o parágrafo único do art. 8o da Constituiçăo Federal e revoga o dispositivo do Decreto-Lei no 221, de 28 de fevereiro de 1967. Diário Oficial da República Federativa do Brasil, Brasília, 16 jun. 2008a. Disponível em: <https://bit.ly/37sBeBo>. Acesso em: 30 mar. 2019.

Ministério da Previdência Social. Portaria MPS no 321, de 8 de outubro de 2008. Diário Oficial da Uniáo, Brasília, p. 24, 9 out. 2008b. Seção 2. Disponível em: <http://sislex.previdencia.gov.br>. Acesso em: 3 fev. 2018.

. Tribunal de Contas da União. Acórdão no 1.795/2014, de 9 de julho de 2014. Plenário. Relator: Aroldo Cedraz. Diário Oficial da Uniáo, Brasília, p. 85, jul. 2014a. Seção 1. Disponível em: <https://bit.ly/2JGApwA>. Acesso em: 3 fev. 2018.

. Medida Provisória no 665, de 30 de dezembro de 2014. Altera a Lei no 7.998, de 11 de janeiro de 1990, que regula o Programa do Seguro-Desemprego, o abono salarial e institui o Fundo de Amparo ao Trabalhador - FAT, altera a Lei no 10.779 , de 25 de novembro de 2003, que dispóe sobre o seguro-desemprego para o pescador artesanal, e dá outras providências. Diário Oficial da União, Brasília, p. 2, 30 dez. 2014b. Seção 1. Disponível em: <https://bit.ly/33G1s22>. Acesso em: 3 fev. 2018.

CAETANO, M. A.-R. et al. Os reflexos das Medidas Provisórias 664 e 665 sobre as pensóes, o abono salarial e o seguro-desemprego em suas modalidades defeso e formal. Brasília: Ipea, 2015. (Texto para Discussão, n. 2067).

CAMPOS, A. G.; CHAVES, J. V. Seguro Defeso: diagnóstico dos problemas enfrentados pelo programa. Brasília: Ipea, 2014. (Textos para Discussão, n. 1956).

CARDOSO, E. S. Pescadores artesanais: natureza, território, movimento social. São Paulo: USP, 2001.

CGU - CONTROLADORIA-GERAL DA UNiÁO. Processo no 00190.103781/2016-79. Brasília: CGU, 2016. No prelo. Disponível em: $<$ https://falabr.cgu.gov.br/>. Acesso em: 15 maio 2017.

COSTA, M. M.; ALVES, M. A.; GOMES, M. V. P. Cotas no serviço público e burocracia representativa. Nexo Jornal, 9 nov. 2016. Disponível em: <https://bit. ly/33Hcx2X>. Acesso em: 28 jan. 2018.

DIAS-NETO, J. Proposta de Plano Nacional de Gestáo para o uso sustentável de camaróes marinhos do Brasil. Brasília: Ibama, 2011. 
ENAP - ESCOLA NACIONAL DE ADMINISTRAÇÃO PÚBLICA. Conheça as iniciativas vencedoras do 22ㅜㅡㄹ Concurso Inovaçáo. Brasília: Enap, 13 ago. 2018. Disponível em: <https://bit.ly/3oij7ow>. Acesso em: 27 jan. 2019.

GOLDSMITH, S.; EGGERS, W. D. Governing by network: the new shape of the public sector. Washington: The Brookings Institution, 2004.

IBGE - INSTITUTO BRASILEIRO DE GEOGRAFIA E ESTATÍSTICA. Estimativas de populaçáo enviadas ao TCU. [s.1.]: IBGE, 1ำ jun. 2017. Disponível em: <https://bit.ly/37BjXWE>. Acesso em: 20 jan. 2018.

INSS - INSTITUTO NACIONAL DO SEGURO SOCIAL. Portaria INSS/ PRES no 1.184 , de 30 de setembro de 2014. Boletim de Serviço do INSS, Brasília, p. 7-9, 30 set. 2014. Disponível em: <https://bit.ly/3qpTlk9>. Acesso em: 3 fev. 2018.

. Memorando-Circular Conjunto no 32/Dirat/Dirben/PFE/INSS, de 8 de outubro de 2015. Sistema de Atos e Normas, Brasília, 8 out. 2015a. Disponível em: <https://falabr.cgu.gov.br/>. Acesso em: 3 fev. 2018.

Instrução Normativa INSS/Pres no 83, de 18 de dezembro de 2015. Diário

Oficial da Uniáo, Brasília, p. 176-177, 22 dez. 2015b. Seção 1. Disponível em: $<$ http://sislex.previdencia.gov.br>. Acesso em: 3 fev. 2018.

. Memorando-Circular Conjunto no 11/Dirben/Dirat/DIROFL/INSS, de 28 de janeiro de 2016. Sistema de Atos e Normas, Brasília, 29 jan. 2016. Disponível em: <https://bit.ly/3lAq0Qb>. Acesso em: 3 fev. 2018.

. Portaria no 91, de 19 de janeiro de 2017. Boletim de Serviço do INSS, Brasília, p. 3-28, 19 jan. 2017. Disponível em: <https://bit.ly/3lB4cnF>. Acesso em: 3 fev. 2018.

Portal do Instituto Nacional do Seguro Social, consulta de notícias por tag. [s.l.]: INSS, 12 mar. 2019. Disponível em: <https://bit.ly/2L5MOeg>. Acesso em: 31 mar. 2019.

LOTTA, G. S. Redes e parcerias em políticas sociais: novos arranjos institucionais de coprodução de serviços nos municípios brasileiros. Brasília: Enap, 2017. (Cadernos Enap, v. 51).

MCGUIRE, M. Collaborative public management: assessing what we know and how we know it. Public Administration Review, v. 66, special issue, p. 33-43, Dec. 2006.

OSBORNE, S. P. et al. The service framework: a public-service-dominant approach to sustainable public services. British Journal of Management, v. 26, n. 3, p. 424-438, 2015. 
O’TOOLE, L. J. Treating networks seriously: practical and research-based agendas in public administration. Public Administration Review, v. 57, n. 1, p. 45-52, 1997. PIRES, R. R. C. Sociologia do guichê e implementação de políticas públicas. Revista Brasileira de Informação Bibliográfica em Ciências Sociais - BIB, n. 81, p. 5-24, 2016.

SCHUPPAN, T. Reassessing outsourcing in ict-enabled public management. Public Management Review, v. 11, n. 6, p. 811-831, 2009.

SILVEIRA, J. P. B. Justiça ambiental e a política do Seguro Defeso na pesca artesanal: o caso da Associaçáo de Pescadores da Praia da Armaçáo do Sul. Ruris, v. 8, n. 1, p. 31-62, 2011.

WEISS, C. H. Evaluation: methods for studying programs and policies. 2. ed. Upper Saddle River: Prentice Hall, 1998. 


\section{APÊNDICE A}

\section{TRATAMENTO DOS DADOS}

Para levantamento dos dados, foram utilizadas a Base de Gestão do Seguro-Desemprego do Ministério do Trabalho e Emprego (MTE), hoje assimilado pelo Ministério da Economia (ME), o Sistema Integrado de Gestão e Monitoramento do Atendimento, do Instituto Nacional do Seguro Social (INSS), e a Base do Registro Geral da Atividade Pesqueira (RGP), à época sob gestão do Ministério da Agricultura, Pecuária e Abastecimento (Mapa).

Foram selecionados e tratados registros dos pescadores por Cadastro de Pessoa Física $(\mathrm{CPF})$, residentes nos municípios abrangidos pela Gerência-Executiva (GEX) de Itabuna e que receberam o Seguro Defeso na primeira etapa do defeso do camarão, em 2015 e 2016.

Para cada CPF, foram consideradas duas observações, em 2015 e 2016. Essas observaçóes apresentam variáveis para o código de endereçamento postal (CEP), o município/Unidade da Federação (UF) de residência, a data de nascimento e inscrição no RGP, o sexo, a agência da Previdência Social (APS) responsável, a entidade mais próxima, as datas de requerimento, a digitação, a habilitação e a disponibilização do benefício.

Como para identificar o local do requerimento se utilizou a residência do pescador, foi verificada a proporção de migraçôes - isto é, pescadores atendidos por unidades diferentes daquelas mais próximas à residência. Em 1.909 registros ocorreram dezesseis migraçóes, o que permitiu desconsiderar o fenômeno.

Foi verificada a presença de outliers nas distribuiçôes de frequência das datas de habilitação do defeso em cada ano (dt.hab15 e dt.hab16), como demonstram os histogramas. 
GRÁFICO A.1

Distribuição de frequência de datas de habilitação (2015)

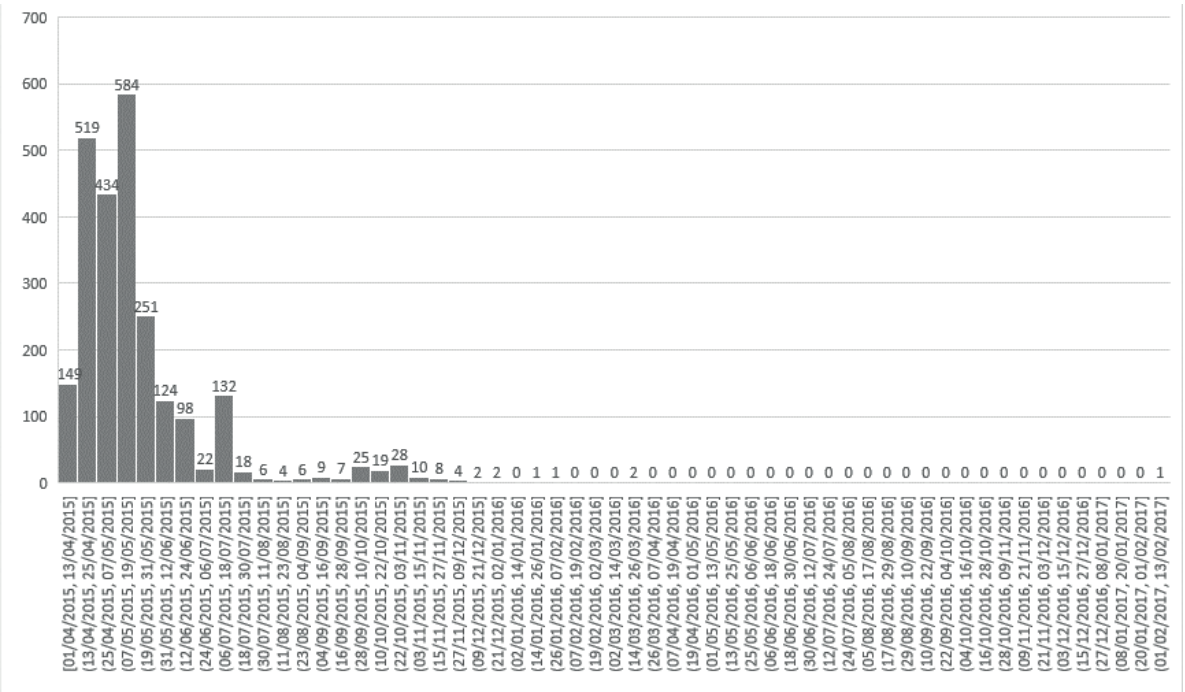

Elaboração do autor.

Obs.: Gráfico cujos leiaute e textos não puderam ser padronizados e revisados em virtude das condições técnicas dos originais (nota do Editorial).

GRÁFICO A.2

Distribuição de frequência de datas de habilitação (2016)

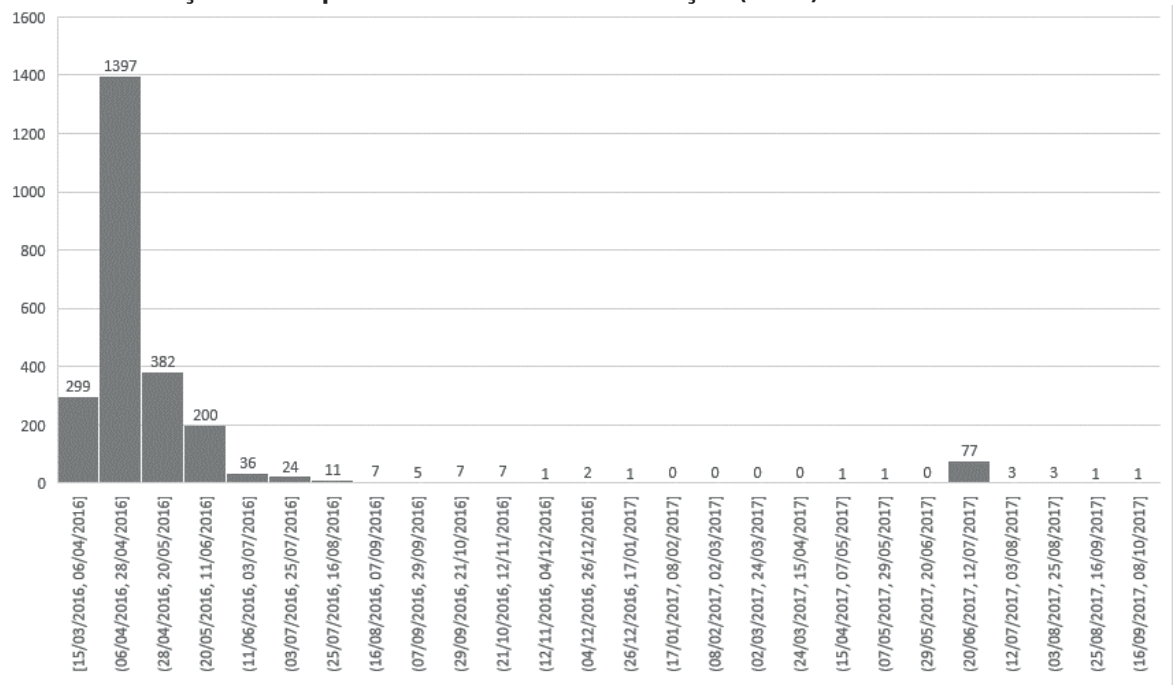

Elaboração do autor.

Obs.: Gráfico cujos leiaute e textos não puderam ser padronizados e revisados em virtude das condições técnicas dos originais (nota do Editorial). 
Os outliers cuja data de habilitação ultrapassou 31 de dezembro do ano do defeso referente ao benefício requerido para investigação foram segregados, e o motivo de sua existência identificado satisfatoriamente.

Para separar o grupo de controle do grupo de tratamento, foi verificada a ocorrência de atendimento em APS por CPF entre dez dias antes da data do protocolo do requerimento e dez dias após a data de sua digitaçáo. Registros com essa condição pertencem ao grupo de controle, ao assumir-se que seu requerimento se deu em atendimento por APS.

FIGURA A. 1

Critério para inclusão no grupo de controle

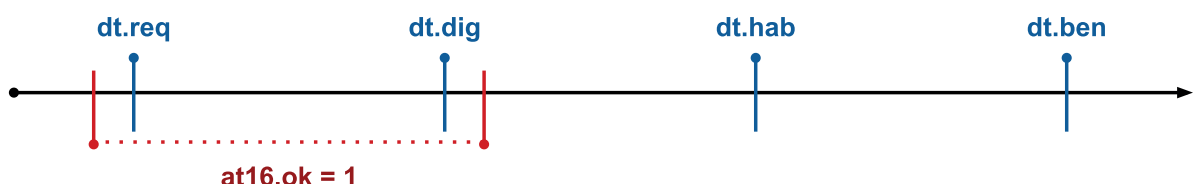

Elaboração do autor.

Para o indicador de tempestividade, temos benpontual $=1$ se a data da disponibilização do benefício $(d t$.ben) for maior que a data do início do defeso mais quarenta dias.

Para aferir diferenças em quilômetros (distmedia), utilizou-se o georreferenciamento da ferramenta Google Maps, via API disponibilizada em <https://developers. google.com/maps>, com CEPs de residência dos pescadores, dos municípios, de APS e de entidades. Os dados foram complementados com informaçôes dos Correios, disponíveis em: <http://www.correios.gov.br>. Foram consideradas as distâncias percorridas por estradas entre os CEPs de residência do pescador e os CEPs das entidades ou APS mais próximas, conforme o grupo e o momento.

Data da submissão: 27/9/2018

Primeira decisão editorial em: 12/3/2019

Última versão recebida em: 2/5/2019

Aprovação final em: 13/5/2019 